or night, and that the fish were present in small shoals of twelve to twenty fish. A local population density of about $2,000,000$ fish per square mile was estimated from the known lens angle and limits of visibility.

\author{
Scottish Home Department, \\ Marine Laboratory, \\ Victoria Road, \\ Torry, \\ Aberdeen.
}

\section{Influence of the Organic Matrix on Crystal Type in Molluscs}

THE calcium carbonate of molluse shells occurs as calcite in some species, as aragonite in others, and certain species deprosit calcite in one portion of the shell and aragonite in another portion. Various explanations have been suggested for the formation of aragonite, which is significantly less stable. Participation of the enzyme carbonic anhydrase and the influence of the protein matrix on which the crystals are deposited have both been suggested. We have investigated the capacity of pieces of decalcified matrix to induce aragonite formation when inserted into a molluse which normally forms only calcite, and also under in vitro conditions in which calcium carbonate is normally precipitated as calcite.

Protein matrix was prepared from shells of the fresh-water clam Elliptio complanatus, from the marine fan shell Atrina rigida, and from the nacreous layer of the Japanese pearl oyster Pinctada martensii by decalcifying with 1 per cent sodium othylenediamine tetraacetate at $p \mathbf{H} \cdot \mathbf{5} \cdot 0$. In each case the shell from which the matrix was taken was aragonite. Microseopic examination of each pioce of matrix showed that all crystalline material had been romoved. To make certain that submicroseopic crystals did not remain, some pieces of matrix wore treated further with $0.01 \mathrm{~N}$ hydrochloric acid. For in vivo studies a single piece of decalcified matrix was wrapped around a fragment of glass cover-slip and inserted between the mantle and shell of the oyster Crassostrea virginica, which deposits a calcite shell. The tomperature of the water was $19-25^{\circ} \mathrm{C}$. The inserted pieces of matrix were removed after various intervals, usually $24 \mathrm{hr}$., washed thoroughly in deionized water, and the crystals identified under the polarizing microscope. In vitro calcification of matrix was carried out at $25 \pm 2^{\circ} \mathrm{C}$. in $100 \mathrm{ml}$. of a calcium bicarbonate solution prepared from reagent grade calcium carbonate in deionized water2. Pieces of decalcified matrix wore placed in this solution for $25-44 \mathrm{hr}$., during which time the $p \mathrm{H}$ rose from $6 \cdot 4$ to $8 \cdot 3$.

Both in vivo and in vitro, aragonite crystals formed on protein matrix from aragonite shells (Table 1). Calcite crystals were also deposited on the matrix in both cascs. The forms of calcite and aragonite crystals were distinct, the former being rhombic or rosette. shaped, and the latter irregular, spherulitic or hexagonal elongate. Aragonite was never found on substrates other than aragonite matrix. Tested substrates and conditions included: (1) glass cover-slip fragments inserted in Crassostrea (25 cases); (2) 'Form. var' plastic inserted in Crassostrea (4 cases); (3) decalcified calcito matrix from prismatic layor of Pinctada inscrted in Crassostrea (3 cases); and (4) decalcified calcite matrix from prismatic layer of Pinctada tested
Table 1

\begin{tabular}{|c|c|c|c|}
\hline Test system & $\begin{array}{l}\text { Source of protein } \\
\text { matrix }\end{array}$ & $\begin{array}{l}\text { Total No. of } \\
\text { matrix pieces } \\
\text { analysed. }\end{array}$ & $\begin{array}{l}\text { No. of matrix } \\
\text { pieces with } \\
\text { aragonite }\end{array}$ \\
\hline In vivo & $\begin{array}{l}\text { Pinctada martensii } \\
\text { Elliptio complanatus } \\
\text { Atrina rigida }\end{array}$ & $\begin{array}{l}4 \\
8 \\
5\end{array}$ & $\begin{array}{l}\text { crystals } \\
2 \\
1 \\
1 *(?)\end{array}$ \\
\hline In vitro & $\begin{array}{l}\text { Pinctada martensii } \\
\text { Elliptio complanatus } \\
\end{array}$ & $\begin{array}{r}5 \\
3 \\
25\end{array}$ & $\begin{array}{l}2 \dagger \\
6 \neq \\
6 \text { or } 7\end{array}$ \\
\hline
\end{tabular}

* The crystals were clustered and could not be analysed. Their form was irregular and different from calcite crystals. $\ddagger$ Final $p$ H $8 \cdot 3$.

in vitro (10 cases). Calcite crystals only were deposited in each of these instances.

Even though froshly secreted matrix might normally induce aragonite formation in aragoniteforming molluses, aragonite induction might well have been prevented in the present experiments by at least three conditions: (1) alteration of the original state of the aragonite matrix; (2) conversion of small aragonite crystals to calcite after deposition; (3) presence of freshly secreted matrix by the calcitoforming host molluse. The finding of aragonite in approximately one-quarter of the cases (Table 1) is accordingly of a higher frequency than might have been anticipated.

The results point to the protein matrix as a factor determining the crystal type in molluses. At present we have no information on molecular spacing of protein matrix of calcite and aragonite shells which might permit profitable spoculation as to possible mechanisms.

This work was aided by a grant from the Office of Naval Research, United States Navy.

Norimitsu Watabe

KARL M. WILBUR

Dopartment of 'Zoology, Duke University,

Durham, North Carolina,

1 Wilbur, K. M., in "Calciflcation in Biological Systems", Amer. Assoc. Ady. Sci., 15-40, Washington, D.C., 1960 .

2 Reitemeier, R. F., and Buehrer, T. F., J. Phys. Chem., 44, 535 (1940).

\section{The Skipper (Scomberesox saurus) in the Southern North Sea and the Thames Estuary}

THE skipper or saury pike is a pelagie fish of the open Atlantic and Meditorranean, ranging from Tristan da Cunha ${ }^{1}$ northwards to the Gulf of Maine and the Bay of Fundy ${ }^{2}$ in the western Atlantic, and to Christiana Fjord and Gjesvaer, near the North Cape, in the European Atlantic ${ }^{3}$. On the southern and south-westorn British coast it is of frequent, if not annual, occurrence, and catches of up to 100,000 have been roported at Mevagissey, Cornwall ${ }^{4}$. Farther north it has often been recorded from the Hebrides, the western Scottish coast and tho Shetland and Orkney Islands ${ }^{5}$, but the number of records decreases noticeably on the eastorn coast of Scotland. Rae (personal communication) has found a specimen off Buchan Noss, Aberdeenshire (November 21, 1957); one in the Moray Firth (Jecember 18, 1958); a shoal at Saltburn, Cromarty Firth (Docember 21, 1958); one at May Island, Firth of Forth (Docombor 1, 1958); and one from a cod stomach $12^{\prime} \mathrm{N}$. St. Abbs, Berwick (February 18, 1959). 